\title{
Comparative Efficiency Evaluation of Different Clay Pots Versus Bucket Irrigation System Under Swiss Chard (Beta vulgaris subsp. cicla) Growers Condition in Northern Ethiopia
}

\author{
A. Araya ${ }^{1}$, Lucieta Guerreiro Martorano ${ }^{2}$, Atkilt Girma ${ }^{3}$, Solomon Habtu ${ }^{4}$, Haile Kebede ${ }^{5}$, Kiros Meles \\ Hadgu $^{6}$
}

1,3\&4 College of Dryland Agriculture and Natural Resources, Mekelle University, Mekelle, ETHIOPIA

${ }^{2}$ Embrapa Eastern Amazon, Belem, Para, BRAZIL

${ }^{5}$ Buraue of Agriculture and Rural Development, Tigray, ETHIOPIA

${ }^{6}$ The International Center for Research in Agro-forestry (ICRAF), Addis Ababa, ETHIOPIA

\begin{abstract}
Rain-fed agriculture shares the largest crop production system in Tigray region. However, due to erratic nature of rainfall, crop production is always at a risk. For this reason crop production in the arid and semi arid regions of northern Ethiopia usually requires supplemental irrigation. In an effort to assist agricultural production under smallholder farmers, the Regional Bureau of Agriculture and Natural Resources has been looking for efficient and less costly irrigation methods. Although drip irrigation technology has been well known for its higher efficiency, its adoption was too slow due to its high initial cost and inadequate technical knowhow. At the moment, in some areas of Tigray farmers have started practicing locally made low cost clay pot irrigation technology. However, the water use efficiency and its economic viability under smallholder farmers were not adequately understood. The objectives of this study were thus to examine the economical viability and estimate the water use efficiency of clay pot irrigation technology and to evaluate the performance of different clay pot design for irrigating Swiss chard (the most common leafy vegetable crop in this region). In this research traditional pot maker was instructed to manufacture four different clay pot designs (imperforated bar type, imperforated round shape type, perforated bar type and perforated round types) which were used for assessing performance of clay pot for irrigating swiss chard. Performance tests were carried out based on economic and biomass water use efficiencies and cost benefit ratios under two groups of farmers (with and without land). The result showed that the imperforated bar shaped clay pots were found to be suited to grow Swiss chard. The water seeps out through the micro pores of the clay pots with relatively slow leaks and long surface wetting time and large area converge around the roots of plants. Contrarly, perforated clay pots leak the water fast through the macro and micro pores and have relatively short wetting time and small area coverage. On the other hand, the difference between imperforated bar and round types were simply the shapes of the pots which is to do with the area coverage along with the rows of the Swiss chard plant. Round types were not as suitable as bar type of the same capacity for row Swiss chard crops due to their small wetting area coverage compared to a similar volume with imperforated bar shaped clay pots type. The economic and biomass water use efficiency for the imperforated bar clay pot design was higher than that of the bucket irrigation system as well as other tested clay pots. The other advantages with imperforated bar clay pots over the bucket type is that the water source is inside the soil thus evaporation is almost nil and there is also less probability of occurrence of leaf disease due to watering and ultimately improving the biomass and economical water use efficiency. However, the technology was not as profitable as the bucket irrigation technique when considering the benefit-cost ratio (BCR) due to costs incurred for purchase of clay pots.
\end{abstract}

Keywords: Climate change adaptation, Clay pot irrigation, Swiss chard, Water use efficiency

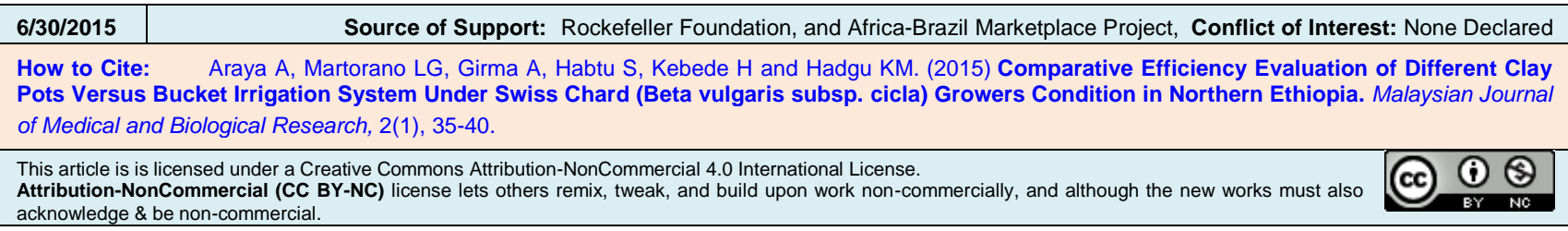




\section{INTRODUCTION}

Ethiopia is one of the sub-Saharan Africa countries that have been affected by climate variability and change. Climate variability and change distorts the hydrological cycle (change in temporal and spatial distribution and intensity of rainfall; increased evapotranspiration and a reduced soil moisture) (Goudie, 2006), and increase the frequency of extreme climate related hazards which consequently affect food security.

Rainfall over the northern Ethiopia is often characterized by convective storms with very high intensity and spatial and temporal variability. The onset and cessation of rain as well as the length of growing season vary from season to season which makes it difficult to rely on rainfed agriculture (Araya and Stroosnijder, 2011). In addition, substantial amount of rainfall is lost through direct evaporation, runoff and deep drainage indicating crop water stress occurs because the available soil water over the growing season is not enough to compensate the crop water requirement. Consequently, drought stress has been one of the most frequent climatic hazards causing severe food shortages in the region. Smallscale water harvesting techniques such as ponds, dams and hand dug wells have been constructed for mitigating long dry spells, especially in rural and drought-prone areas of Ethiopia. However, mismanagement of water has been one of the major existing challenges due to poor access to efficient irrigation application system. Therefore, there needs a better approach to improve water security in order to meet the growing water and food demands on a sustainable basis. Locally made affordable technologies that improve the efficiency of existing small-scale irrigation schemes are required. Such practices could have an impact on climate change adaptation, food security and sustainability of the livelihood. Low cost porous clay pots were tested for irrigating various fruits and vegetable crops in many part of the world and reported to significantly reduce field application losses (evaporation and drainage) (Bainbidge, 2001; Daka, 2001; Okalebo et al., 1995; Wolde-Georgis, 2010). Reports indicated that the advantages of using clay pot irrigation technologies are many among others: very efficient, manufactured locally, affordable, require less labour and less skill, can be used in mountainous and raged topography like in northern Ethiopia, and materials are environmentally friendly and maintains good soil structure and hence are useful for peasant farmers to successfully grow fruit trees and vegetables and reduce impacts of climate change and variability on crop production (Bainbidge, 2001; Daka, 2001; Okalebo et al., 1995; Wolde-Georgis, 2010). Using clay pots irrigation technology was also reported to be many times more efficient than using other water saving technologies (Bainbidge, 2001).

However, the clay pot technology has not been promoted and used due lack of adequate information and lack of crop specific suitable standard design. According to Siyal and Skaggs (2009), enhancing the performance of clay pot irrigation technology needs developing better operational guides and technical standards. There have been knowledge gaps on the technical use of buried porous clay pots for irrigating high value crops such as vegetables and fruit crops under smallholder farmers in the dry land areas. In addition, there has been little quantitative information on the efficiency and economic viability of the technology under farmer's condition. Therefore, the objectives of this research were:

- To study the biomass and economic water use efficiency of clay pot irrigation designs for growing small scale Swiss chard crop under with and without land owner conditions.

- To analyze the benefit cost ratio and to evaluate clay pot design in comparison with the bucket irrigation system for growing Swiss chard under small scale farmers condition.

\section{MATERIALS AND METHOdS}

\section{Study site}

The study site is located $777 \mathrm{~km}$ north of Addis Ababa found in the regional state of Tigray. The experiment was carried out at Mekelle University experimental site (lat. 13.28o N and long. 39.6o E) with an elevation of 2212 meters above sea level. The long term (1980 - 2012) daily climate data that includes daily temperature (min. and max.) and rainfall data were obtained from the national meteorological agency (NMA). The mean annual rainfall and evapotranspiration for the site were about $600 \mathrm{~mm}$ and $1700 \mathrm{~mm}$, respectively. According to Araya et al. (2010) the climate of the site is categorized as semi-arid. About $70-80 \%$ of the rainfall is received during the main rain season (June to September). The soil is categorized as Cambisol with silt clay loam $(0$ to $40 \mathrm{~cm})$ and sandy loam $(40-60 \mathrm{~cm})$. The physical characteristics of the experimental site are shown in Table 1.

Table 1: Soil physical characteristics of experiment site

\begin{tabular}{|c|c|c|c|c|c|c|}
\hline $\begin{array}{c}\text { Soil depth } \\
\mathrm{cm}\end{array}$ & $\begin{array}{c}\text { FC } \\
(\mathrm{Vol} \%)\end{array}$ & $\begin{array}{c}\text { PWP } \\
(\mathrm{Vol} \%)\end{array}$ & Sand (\%) & Silt (\%) & Clay (\%) & Soil texture \\
\hline $0-20$ & 32.04 & 14.28 & 55 & 24 & 21 & Silt clay loam \\
\hline $20-40$ & 37.45 & 19.33 & 50 & 26 & 24 & Silty clay loam \\
\hline $40-60$ & 30.62 & 19.01 & 64 & 20 & 16 & Sandy loam \\
\hline
\end{tabular}

FC, field capacity; PWP, permanent wilting point. 


\section{Treatments and experimental setup}

The treatments were four clay pot designs having equal water holding capacity: imperforated bar type (width $=0.1 \mathrm{~m}$ and height $0.1 \mathrm{~m}$ and length $0.5 \mathrm{~m}$, total capacity $=5$ litres); perforated bar type (width $=0.1 \mathrm{~m}$ and height $0.1 \mathrm{~m}$ and length $0.5 \mathrm{~m}$, total capacity $=5$ litres); imperforated round type (capacity $=5$ litters); perforated round type (capacity $=5$ litres); control (direct water application method). Each treatment was repeated three times. There were 15 plots each of which had an area of $2 \mathrm{~m} 2$. Pots were installed in the plots at intervals of $0.3 \mathrm{~m}$ between rows as treatment and were arranged in randomized complete block design. Swiss chard (Beta vulgaris subsp. cicla) was planted from seeds. Seeds were sown in a wet soil then thinned to a recommended spacing of $0.3 \mathrm{~m}$ between rows and $0.1 \mathrm{~m}$ between plants. Each plot was made to have 48 Swiss chard plants. The control was bucket irrigation system which is the application of irrigation water directly into the plants along sides of the rows in the plots (with out pot).

\section{Crop management}

Swiss chard was fertilized with $\mathrm{N}$ and P of 110 and $138 \mathrm{~kg} / \mathrm{ha}$, respectively. Nitrogen was applied twice in split (half at sowing and the other half 45 days after planting) whereas phosphorus was applied once at sowing. Irrigation was carried out from sowing to final harvest depending on the distribution of rainfall. Irrigation was done by refilling with five litters of water per pot (40 litters per plot) over seven days interval after the cessation of rain. During the rainy period the frequency depend on occurrence of dry spell. The total amount of supplementary irrigation applied per treatment was equivalent to $1800 \mathrm{~m}^{3} /$ ha (Table 2).

Table 2: Rainfall received and irrigation water applied over the growing season (June- September)

\begin{tabular}{|c|c|c|c|}
\hline $\begin{array}{c}\text { Rain } \\
\text { received } \\
(\mathrm{mm})\end{array}$ & $\begin{array}{c}\text { Applied } \\
\text { Irrigation } \\
(\mathrm{mm})\end{array}$ & $\begin{array}{c}\text { Sum total irrigation } \\
\text { applied \& rain } \\
\text { received }(\mathrm{mm})\end{array}$ & $\begin{array}{c}\text { Total water } \\
\left(\mathrm{m}^{3} / \mathrm{ha}\right)\end{array}$ \\
\hline 299.8 & 180 & 479.8 & 4798 \\
\hline
\end{tabular}

\section{Data collection and analysis}

Rainfall data was measured using rain gauge installed on the site. Irrigation water was measured and applied using a gauged watering bucket. Fresh biomass weight of Swiss chard was first harvested 45 days after planting. The biomass was then sequentially harvested five times every 10 days from an area of $2 \mathrm{~m}^{2}$ (Table 3). The marketable fresh weight and market prices were recorded every 10 days, and the gross income was calculated from the sales of fresh biomass per season (Table 4). Biomass Water Use Efficiency (BWUE) was estimated as the amount of fresh marketable biomass $(\mathrm{kg})$ of Swiss chard per amount of water applied $\left(\mathrm{m}^{3}\right)$. Economic Water Use Efficiency (EWUE) was calculated as the net return from the sales of fresh biomass $(\mathrm{kg})$ divided by the amount of water applied $\left(\mathrm{m}^{3}\right)$. Benefit Cost Ratio (BCR) was calculated as the present value of total net income divided by the present value of total cost. In general, a benefit cost ratio higher than 1 indicates that the project is economical. Thus the higher the BCR, the more economic the project is, conversely, with the BCR of less than one a project would be uneconomical. With a $\mathrm{BCR}$ closer to one a project would be marginal.

Table 3: Swiss chard fresh biomass harvest in 10 days interval

\begin{tabular}{|c|c|c|c|c|c|c|}
\hline Treatment & $\begin{array}{c}1 \text { st } \\
\mathrm{kg} / \mathrm{ha}\end{array}$ & $\begin{array}{c}2 \mathrm{nd} \\
\mathrm{kg} / \mathrm{ha}\end{array}$ & $\begin{array}{c}3 \mathrm{rd} \\
\mathrm{kg} / \mathrm{ha}\end{array}$ & $\begin{array}{c}4 \text { th } \\
\mathrm{kg} / \mathrm{ha}\end{array}$ & $\begin{array}{c}5 \text { th } \\
\mathrm{kg} / \mathrm{ha}\end{array}$ & $\begin{array}{c}\text { Total } \\
\mathrm{kg} / \mathrm{ha}\end{array}$ \\
\hline $\mathrm{A}$ & 10700 & 14000 & 12600 & 14000 & 20000 & 71200 \\
\hline $\mathrm{B}$ & 13700 & 9100 & 10900 & 9700 & 5200 & 48600 \\
\hline $\mathrm{C}$ & 8600 & 9000 & 8900 & 10300 & 6200 & 42900 \\
\hline $\mathrm{D}$ & 12000 & 9200 & 9400 & 8900 & 5300 & 44700 \\
\hline $\mathrm{E}$ & 11800 & 11100 & 11900 & 8600 & 6400 & 49700 \\
\hline
\end{tabular}

The first biomass was harvested 45 days after planting. $\mathrm{A}=$ imperforated bar type; $\mathrm{C}=$ perforated bar type; $\mathrm{B}=$ imperforated round type; $\mathrm{D}=$ perforated round type; $\mathrm{E}=$ control.

Table 4: Gross income from sale of Swiss chard under the different treatments

\begin{tabular}{|c|c|c|c|c|}
\hline \multirow{2}{*}{ Treatment } & \multicolumn{3}{|c|}{$\begin{array}{c}\text { Six season's gross income (birr/ha) } \\
\text { from sales of Swiss chard }\end{array}$} & \\
\cline { 2 - 5 } & Rep 1 & Rep 2 & Rep 3 & Mean (birr/ha) \\
\hline A & 480569 & 433390 & 509758 & $474572 \mathrm{a}$ \\
\hline B & 322389 & 293100 & 367286 & $327592 \mathrm{bc}$ \\
\hline C & 283540 & 272518 & 304331 & $286797 \mathrm{c}$ \\
\hline D & 250263 & 301945 & 351813 & $301340 \mathrm{bc}$ \\
\hline E & 327743 & 283427 & 397890 & $336353 \mathrm{~b}$ \\
\hline
\end{tabular}

$\mathrm{A}=$ imperforated bar type; $\mathrm{C}=$ perforated bar type; $\mathrm{B}=$ imperforated round type; $\mathrm{D}=$ perforated round type; $\mathrm{E}=$ control. 


\section{Scenarios and assumptions}

Our scenario analysis for clay pot performance evaluation was based on two groups of farmers: the first group has farm land and the second group of farmer is landless. The second groups of farmers are assumed to rent land from farmers with extra land. We assumed that both groups of farmers also have access to irrigation. Clay pot functioning life span was estimated to be two years. Based on the present research growing Swiss chard took about four month from sowing to final harvest during which five fresh biomass harvests were carried out. As there were no other constraints except water, three growing season per year were assumed. The income obtained per season was multiplied by six seasons during which clay pot irrigation systems was expected to be operational. Production cost and market prices were assumed constant over the projected two years period. The profitability of the scenarios was then assessed based on benefit cost ratio, economic and biomass water use efficiency.

\section{RESULTS AND Discussion}

\section{EWUE and BWUE}

In scenario - I of this study, the biomass water use efficiency (BWUE) for Swiss chard ranged from $8.9 \mathrm{~kg} / \mathrm{m}^{3}$ for treatment with perforated bar type clay pot design to $14.8 \mathrm{~kg} / \mathrm{m}^{3}$ for treatment with imperforated bar type clay pot design (Table 5 and 6). The relatively higher BWUE in imperforated clay pot design was attributed to the better and uniform water distribution both in time (slow leak saves water and maintains uniform distribution) and area coverage. In scenario - I, the Economic Water Use Efficiency (EWUE) under imperforated bar type (68.7 birr $\left./ \mathrm{m}^{3}\right)$ was also higher than the other treatments for similar reasons mentioned above. Bucket irrigation has shown higher EWUE compared clay pot irrigation designs with the exceptions of imperforated bar type. The major reasons for higher performance of the bucket irrigation (control) were due to direct and controlled application of irrigation water into the plants (minimal field application and conveyance water loss). In addition, the prescheduled irrigation water was calculated considering bucket irrigation practice for Swiss chard.

However, the EWUE in control (bucket irrigation) was slightly lower than the imperforated bar type which could be attributed to the evaporation losses as the water is applied on the surface unlike the subsurface water delivery by the imperforated clay pot. In addition, in bucket irrigation, some of the water applied directly into the plants might flow below the rooting zone through the cracks in the soil. Like in scenario - I, BWUE and EWUE in scenario - II were higher in treatments with imperforated bar type clay pot designs followed by control (bucket irrigation) (Table 6). The difference between the bucket and imperforated clay pot irrigation treatment was not big but the EWUE for the other treatments were by far lower than both bucket and imperforated clay pot. The gross income obtained from imperforated clay pots was also significantly higher than the other treatments (Table 4).

Table 5: Total projected biomass, net income, BWUE, EWUE, BCR from Swiss chard projected based on six season clay pot operational life under Scenario-I

\begin{tabular}{|c|c|c|c|c|c|c|c|c|}
\hline Tr & $\begin{array}{c}\text { Biomass } \\
(\mathrm{kg} / \mathrm{ha})\end{array}$ & $\begin{array}{c}\text { Gross income } \\
\text { birr/ha })\end{array}$ & $\begin{array}{c}\text { Total cost } \\
\text { birr } / \mathrm{ha}\end{array}$ & $\begin{array}{c}\text { Net Income } \\
(\text { birr } / \mathrm{ha})\end{array}$ & $\begin{array}{c}\text { Water requirement } \\
\left(\mathrm{m}^{3} / \mathrm{ha}\right)\end{array}$ & $\begin{array}{c}\text { BCR } \\
()\end{array}$ & $\begin{array}{c}\text { BWUE } \\
\mathrm{kg} / \mathrm{m} 3\end{array}$ & $\begin{array}{c}\text { EWUE } \\
\mathrm{birr} / \mathrm{m}^{3}\end{array}$ \\
\hline A & 427200 & 2847434 & 869840 & 1977594 & 28788 & 3.27 & 14.8 & 68.7 \\
\hline B & 291600 & 1965550 & 869840 & 1095710 & 28788 & 2.26 & 10.1 & 38.1 \\
\hline C & 257400 & 1720779 & 869840 & 850939 & 28788 & 1.98 & 8.9 & 29.6 \\
\hline D & 268200 & 1808042 & 869840 & 938202 & 28788 & 2.08 & 9.3 & 32.6 \\
\hline E & 298200 & 2018119 & 69840 & 1948279 & 28788 & 28.9 & 10.4 & 67.7 \\
\hline
\end{tabular}

Where, $\mathrm{Tr}$, is treatment; $\mathrm{BCR}$, is benefit cost ratio; BWUE, biomass water use efficiency; EWUE, economic water use efficiency; $\mathrm{A}=$ imperforated bar type; $\mathrm{C}=$ perforated bar type; $\mathrm{B}=$ imperforated round type; $\mathrm{D}=$ perforated round type; $\mathrm{E}=\mathrm{control}$.

Table 6: Total projected biomass, net income, BWUE, EWUE, BCR from Swiss chard projected based on six season clay pot operational life under Scenario -II

\begin{tabular}{|c|c|c|c|c|c|c|c|c|}
\hline Tr & $\begin{array}{c}\text { Biomass } \\
(\mathrm{kg} / \mathrm{ha})\end{array}$ & $\begin{array}{c}\text { Gross income } \\
\text { birr/ha) }\end{array}$ & $\begin{array}{c}\text { Total cost } \\
\text { birr } / \text { ha }\end{array}$ & $\begin{array}{c}\text { Net Income } \\
(\text { birr } / \mathrm{ha})\end{array}$ & $\begin{array}{c}\text { Water requirement } \\
\left(\mathrm{m}^{3} / \mathrm{ha}\right)\end{array}$ & $\begin{array}{c}\text { BCR } \\
()\end{array}$ & $\begin{array}{c}\text { BWUE } \\
\mathrm{kg} / \mathrm{m} 3\end{array}$ & $\begin{array}{c}\text { EWUE } \\
\text { birr } / \mathrm{m}^{3}\end{array}$ \\
\hline A & 427200 & 2847434 & 911840 & 1977594 & 28788 & 2.1 & 14.8 & 67.24 \\
\hline B & 291600 & 1965550 & 911840 & 1095710 & 28788 & 1.2 & 10.1 & 36.6 \\
\hline C & 257400 & 1720779 & 911840 & 850939 & 28788 & 0.9 & 8.9 & 28.1 \\
\hline D & 268200 & 1808042 & 911840 & 938202 & 28788 & 1 & 9.3 & 31.13 \\
\hline E & 298200 & 2018119 & 111840 & 1948279 & 28788 & 17 & 10.4 & 66.22 \\
\hline
\end{tabular}

Where, BCR, is benefit cost ratio; BWUE, biomass water use efficiency; EWUE, economic water use efficiency; $\mathrm{A}=$ imperforated bar type; $\mathrm{C}$ = perforated bar type; $\mathrm{B}=$ imperforated round type; $\mathrm{D}=$ perforated round type; $\mathrm{E}=$ control. 


\section{Benefit Cost Ratio (BCR)}

Of the clay pot irrigation designs, highest and lowest BCR were recorded for imperforated and perforated bar type design with a value of 3.27 and 1.98 under scenario - I and 2.1 and 0.9 under senario - II, respectively. According to the $\mathrm{BCR}$ analysis, most of the tested clay pots types were economically viable with the exceptions of perforated bar type under scenario - II. The benefit cost ratio for scenario I are generally higher than that of scenario II for because land costs are not considered under senario - I (Table 5 and 6). Generally, most of the clay pot treatments under senario I and II were economically viable because the income from the total sales of fresh Swiss chard were higher than the cost of production. On the other hand, bucket irrigation (control) was more profitable than the clay pot irrigation technology because the investment cost was almost zero. The bucket irrigation is one of the most common irrigation methods used for fruit with home garden growers in northern Ethiopia.

\section{Performance evaluation of clay pot irrigation system}

Clay pot irrigation system was reported to improve irrigation uniformity and water use efficiency for different crops through its self regulated irrigation system (Sheikh and Shah, 1983; Power, 1985; Batchelor et al. 1996, Hagazi, 1998; Bainbridge, 2001; Ashrafi et al., 2002).

According to this study, pots with moderately slow leaks (as in imperforated clay pot type) were desirable for irrigating shallow rooted crops like Swiss chard. Reports showed that the water outflow from clay pots depend on many pot's characteristics including wall thickness, firing temperature, sand to clay ratio from which the pot is made (Abu-Zreigand Atoum, 2004; Tesfaye et al., 2011). Furthermore, water flow from the pores of pots was also reported to be regulated by external factors among others by the water needs of neighbouring plants, evapotranspiration demand of the atmosphere and osmotic status of the soil (Daka, 2001; Bainbridge, 2001). Some reports also showed that water leak from porous pots could be affected by saturated hydraulic conductivity of the clay pot, surface area, soil texture and crop type (Abu-Zreigand Atoum, 2004; Siyal and Skaggs 2009).

Results of this study showed that clay pot design determine the water distribution around the roots of the experimental plant and hence determine the crop water productivity. Pots with round shape were not as efficient as those bar types because Swiss chard is a shallow rooted crop grown in rows whose water demand might be met by using a bar pots buried closely in parallel along the rows of Swiss chard plant.

On the other hand, the imperforated (naturally with micro pores) clay pots were more efficient than the perforated types. In imperforated clay pots, water outflow was slow and most likely regulated by water needs of the plant and maintain uniform water distribution for relatively longer period of time. However this was not the case with those artificially perforated clay pot designs which have macro holes to pass water more rapidly and freely. In this case, the water outflow was not regulated by the water need of the surrounding plants.

Imperforated types are self regulated which depends on the availability of soil water in the rooting zone. The water outflow from the clay pot stops when the when the soil becomes wet and water outflow slowly starts again when the soil becomes dry. The imperforated clay pot types have achieved relatively higher water and economic water use efficiency with relatively higher benefit cost ratio and productivity.

\section{CONCLUSION}

Of all clay pot types, the bar shaped imperforated clay pots were identified as superior for irrigating Swiss chard. However farmers may not be interested because: the high investment cost of clay pot; clay pots may sometimes hinder farm operation and are fragile; making the required shape/design could be difficult and time taking for traditional pot makers. Therefore, we recommend that small scale clay pot manufacturing industries should be introduced to support the efforts of saving available water for agriculture. Clay pot may be used potentially to irrigate small scale home garden vegetables or fruit crops which could enable farmers supplement additional household income (Bainbridge, 2001). In this study, the technology was found to be economically viable under small scale Swiss chard home garden growers condition although was much lower than the bucket irrigation technology. The benefit cost ratio for bucket irrigation was found to be very attractive compared to clay pot designs. Therefore, farmers should consider the cost of and benefits when they consider purchasing irrigation technology.

\section{ACKNOWLEDGEMENT}

Authors would like to thank Rockefeller Foundation and Africa-Brazil Marketplace project for supporting this research. 


\section{REFERENCES}

Abu-Zreig, M. M., and Atoum M. F., 2004. Hydraulic characteristics and seepage modeling of clay pitchers produced in Jordan. Canadian biosyst. eng. 46.

Araya, A., and Stroosnijder, L., 2011. Assesing drought risk and irrigation need in northern Ethiopia. Agroc. For. Meteorol., 151, $425-436$

Araya, A., Keesstra, S. D. and Stroosnijder, L., 2010. A new agro-climatic classification for crop suitability zoning in northern semi-arid Ethiopia. Agric. For. Meteorol. 150, 1047-1064.

Ashrafi, S., Gupta, A., Singh, M.B. , Izumi, N. , Loof, R., 2002. "Simulation of Infiltration from Porous Clay Pipe in Subsurface Irrigation".Hydrol. Sci. J. 47(2), 253268.

Bainbridge, D.A., 2001. Buried clay-pot irrigation: little-known but very efficient traditional method of irrigation, Agricultural water Management 48(2), 79-88.

Batchelor, C., Christopher, L., Murata, M.,1996. "Simple Micro-irrigation Techniques for Improving Irrigation Efficiency on Vegetable Gardens".Agricultural Water Management. 32, 37-48.

Daka, A.E., 2001. Chapter 7 Clay pot sub-surface irrigation as water-saving technology for small-farmer irrigation in Development of technological package for sustainable use of Dambos by small-scale farmers, PhD Thesis, University of Pretoria, South Africa.

Goudie, A., 2006. Global Warming and Fluvial Geomorphology. Geomorphology. 79, 3-4, 384-394

Hegazi, S.M., 1998. "Subsurface Irrigation Method using Porous Clay Pipe". Progress Report, Iranian Agricultural Education and Research Institute, Agricultural Research and Education Organization, Ministry of Agriculture, Iran.

Okalebo, J.A., Home, P.G., Lenga, F.K., 1995. Pitcher irrigation: a new irrigation technique to curb the effects of Stalinization. In: Proceedings of the $7^{\text {th }}$ Conference of the society of Agricultural Engineers on Engineering the Economy, Jomo Kenyatta University of Agriculture and Technology, Nairobi, Kenya, 15-21.

Power, G. 1985. "Porous Pot Help Crop to Grow in North Eastern Brazil".World Water. July, 21-23.

Raihana B. 2012. Trend in Productivity research in Bangladesh Agriculture: A Review of selected Articles. Asian Business Review, 1, 1-4.

Sheikh, M.I. and B.H. Shah. 1983. “Establishment of Vegetation with Pitcher Irrigation”. Pakistan J. For. 33(2):75-81.

Siyal, A. A., and Skaggs, T. H., 2009. Measured and simulated soil wetting patterns under porous clay pipe sub-surface irrigation. Agric. Water Manag. 96, 893-904

Tesfaye, T., Tesfaye, K., and Woldetsadik, K., 2011. Clay Pot Irrigation for Tomato (Lycopersicon esculentum Mill) Production in the North East Semiarid Region of Ethiopia. J. Agr. Rural Develop. Trop. Subtrop. 112 -1, 11-18

Wolde-Georgis , T., 2010. Testing the use of clay pots sub-surface irrigation methods for dry land farming in Atsebes, Ethiopia, Progress Report to the directors of Conservation, Food E Health Foundation. Consortium for Capacity Building, Univ.of Colorado, Boulder.

Ziervogel, Gina, Anthony Nyong, Balgis Osman, Cecilia Conde, Sergio Cortés, and Tom Downing, 2006. Climate Variability and Change: Implications for Household Food Security, AIACC Working Paper No. 20 January. 